\title{
Evaluation of Improved Tomato Varieties (Lycopersicon Esculentum Mill.) Performance against Major Insect Pests Under Open Field and Glasshouse Conditions
}

\author{
Tadele Shiberu \\ Department of Plant Sciences, College of Agriculture and Veterinary Sciences, \\ Ambo University, Ethiopia \\ tshiberu@yahoo.com
}

\begin{abstract}
This study was conducted under both open field and glasshouse conditions at Ambo University during the main cropping season of 2013-2014 using six different improved tomato varieties 'Miya', 'Chali', 'Fetan', 'Melka-selsha', 'Melka shola', 'Cochoro' and 'Local round' which were evaluated for their general performance, and resistance to insect pests The Randomized Complete Block Design (RCBD) was adopted with three replications. The result of the study revealed significant $(P<0.001)$ differences for all parameters measured.. The maximum number of primary branches per plant was recorded in the varieties, 'Chali' (5.67), Miya' (5.33), and 'Melka shola' (5.0) and the minimum number of primary branches per plant was recorded in variety, 'Fetan' (3.73). The maximum number of fruits per plant was recorded in 'Melka shola' (75.33) followed by 'Melka-Selsa' (64.33), while 'Fetan' and 'Mira-1'variety hadthe minimum fruit numbers of (15.0and 15.67), respectively. The maximum marketable and non-marketable fruit yield per plant was observed in 'Chali' (2.0 kg/plant) and the minimum was in 'Melka selsa' $(0.9 \mathrm{~kg} /$ plant $)$ under open field. But in glasshouse, the maximum marketable yield $(2.06 \mathrm{~kg} /$ plant $)$ and the minimum $(0.31 \mathrm{~kg} / \mathrm{plant})$ was recorded in 'Melka shola' and 'Chali'. Regarding insect pests and diseases, the varieties were significantly $(P<0.001)$ different. The highest insect damage by fruit borer was in 'Miya' $(4.33 \%$ / plant) and the minimum was observed in 'Melka shola' (1.67\% / plant) under open field but in glass house condition, the maximum and the minimum was scored in 'Melka selsa'(4.67\% / plant) and in 'Fetan'(1.0\% / plant). Considering the total fruit yield, the maximum yield was recorded in 'Chali' $(3.24 \mathrm{~kg} /$ plant) and the minimum was in 'Fetan' $(1.13 \%$ / plant) under open field but in glasshouse condition, the maximum fruit yield was recorded in 'Melka shola' (4.04 kg/plant) and the minimum in 'Cochoro' (1.61 kg / plant). This study was concluded that the tomato varieties, 'Melka shola' and 'Fetan' showed relatively good and poor performance in all parameters, respectively. Growing conditions within a glasshouse could be significantly different from growing conditions in open field production.
\end{abstract}

Keywords: Performance, Tomato varieties, Yield, Pests, Glasshouse, Open field

\section{INTRODUCTION}

Tomato is an economically important crop among vegetable crops in the country. Central Statistics Authority of Ethiopia reported that Ethiopia is the world's $84^{\text {th }}$ largest producer of tomato (CSA, 2012). Tomato for consumption as fresh produce is produced under green-house conditions as well as in open fields. The crop is of high economic importance in the West Shoa of Ethiopia. A total of 7,255.93 hectares of land was under tomato in the country and yielding about 81,738.05 tones of tomato production in Ethiopia (CSA, 2012). Tomato is a high economical importance in West Shoa of Ethiopia. It is consumed in every household in different styles, but in certain areas, such as Walo, Hararge, Shawa, Jimma and Wallaga, it is also an important co-staple food (Ambecha et al., 2012). It can be eaten either fresh or processed into different products. It is helpful in healing wounds because of antibiotic properties found in ripe fruits. It is good source of Vitamins A, B and C (Baloch, 1994).

According to Birhanu and Ketema (2010) in Ethiopia, the crop is grown between 700 and 2000 meter above sea level with about 700 to over $1400 \mathrm{~mm}$ annual rain fall, in different areas and seasons, in different soils, under different weather conditions, at different levels of technology and yield. However, there is no information on tomato cultivar performance under glasshouse. Thus, the current research activities was conducted to identify the general performance of improved varieties yield in production, disease and pest resistance status at the level of individual variety by identifying the 
status under both open field and glasshouse conditions. No attempts have been made to assess each improved tomato varieties for general performance under both conditions simultaneously. Therefore, the objective of this study was to evaluate the general performance of improved tomato varieties under open field and glasshouse conditions.

\section{MAterials AND Methods}

\subsection{Description of the Study Area}

The study was conducted under open field and glasshouse conditions at Ambo University Research Farm during the main cropping season of 2013-2014. Ambo is112 km from Addis Ababa and found on latitude $08^{\circ} 59^{\prime} .078^{\prime}$ North and longitude $037^{\circ} 50.704^{\prime}$ East, with an altitude of 2072 m. a. s. 1 . and located in Oromia Regional State Western Shoa Zone, Ethiopia..

The treatments consisted of six improved tomato varieties 'Miya', 'Chali', 'Fetan', 'Melka-salsa', 'Cochoro' and 'Melka shola' obtained from the Melkasa Agricultural Research Center and 'Local round' variety collected from Ambo was used as a control treatment. Seedlings were raised in nursery bed separately at Ambo University Research Farm; the bed was thoroughly prepared $1.5 \mathrm{~m} \mathrm{x} 1 \mathrm{~m}$ size each within seven beds. The seed was sown in rows. The nursery was irrigated water every day during after noon. The experiment was laid out in a randomized complete block design (RCBD) with three replications. The seedlings were transplanted after 45 days to experimental treatment plots which were laid out $1.6 \times 2.4$ meter in dimensions. The space between plant $30 \mathrm{~cm}$ and between rows $80 \mathrm{~cm}$ as an average recommended (60-100) cm between rows. The space between two plots $50 \mathrm{~cm}$ and between blocks 1 meter under open field. All agronomic practices, fertilizer application and irrigation frequencies were carried out according to the recommendations of the Ethiopian institute of Agricultural Research (EARO, 2004). Under glasshouse condition 18 pots were prepared and filled with compost, loam soil and sand soil in the ratio of 1:1:2, respectively. Pot size measured $25 \mathrm{~cm}$ height and $20 \mathrm{~cm}$ diameter was used. Each treatment had three pots as replications.

\subsection{Data Collection}

Data were collected with the number of primary branches at flowering stage, number of fruit per plant, number of leaf infested/damaged, number of fruit infested/bored by insect pests and diseases per plant, marketable and unmarketable fruit yield per plant in $\mathrm{kg}$, Average total yield per plant were taken by adding marketable and unmarketable fruit yield. During the study period, the average temperature and relative humidity were taken in both open field and in glasshouse conditions.

\subsection{Data Analysis}

The data collected for each treatment were subjected to analysis of variance for Randomized Complete Block Design (RCBD). The mean comparisons were carried out using Duncan's Multiple Range Test (DMRT). SAS statistical software package (SAS, 2000) was employed for analysis of variance of the experiment. The statistical significance was determined by using F-test. Mean standard error (MSE) was used to separate the mean performance of the varieties which were significantly different (Montgomery, 2005).

\section{RESUlTS AND DiSCUSSION}

\subsection{Number of Branches}

Under open field condition the number of branches per plant were significantly $(\mathrm{P} \leq 0.001)$ different among the varieties (Table 1). All tomato varieties tested to achieve the maximum number of branches per plant. The maximum number of primary branches per plant was recorded in the varieties, 'Chali' (5.67), Miya' (5.33), and 'Melka shola' (5.0) and the minimum number of primary branches per plant was recorded in variety, 'Fetan' (3.73). This study was disagreeing with the previous work of Meseret et al. (2012) and reported that the varieties, Fetan' and 'Miya' was not significantly different with the number of branches under field condition. Despite of this, under glasshouse condition number of branches indicated that significantly $(\mathrm{P}<0.001)$ different among the treatments. 'Kochoro' and 'Melka shola' revealed the maximum number of branches (5.33) and (5.0), respectively. 'Fetan', 'Miya' and 'local round' showed the minimum primary branch number per plant (Table 3). These results were in close conformity with the findings of Meseret et al. (2012) who reported that the significant variations among the varieties of tomato for the number of branches per plant. 
Evaluation of Improved Tomato Varieties (Lycopersicon esculentum Mill.) Performance against Major Insect Pests under Open Field and Glasshouse Conditions

Table1. Number of branch, number of fruit, marketable yield and non-marketable yield per plant under open field condition.

\begin{tabular}{|l|l|l|l|l|}
\hline Treatments & $\begin{array}{l}\text { No.of branches } \\
\text { per plant }\end{array}$ & $\begin{array}{l}\text { Numbe of fruit } \\
\text { per plant }\end{array}$ & $\begin{array}{l}\text { Marketable yield per } \\
\text { plant in kg }\end{array}$ & $\begin{array}{l}\text { Non-marketable yield } \\
\text { per plant in kg }\end{array}$ \\
\hline Miya & $5.33 \mathrm{a}$ & $15.67 \mathrm{~d}$ & $1.3 \mathrm{~b}$ & $0.19 \mathrm{~cd}$ \\
\hline Chali & $5.67 \mathrm{a}$ & $36.67 \mathrm{c}$ & $2.0 \mathrm{a}$ & $1.25 \mathrm{~b}$ \\
\hline Fetan & $3.73 \mathrm{~b}$ & $15.0 \mathrm{~d}$ & $0.5 \mathrm{~d}$ & $0.63 \mathrm{~d}$ \\
\hline Melka salsa & $4.87 \mathrm{ab}$ & $64.33 \mathrm{~b}$ & $1.05 \mathrm{bc}$ & $0.94 \mathrm{c}$ \\
\hline Melka shola & $5.0 \mathrm{a}$ & $75.33 \mathrm{a}$ & $0.9 \mathrm{c}$ & $1.79 \mathrm{a}$ \\
\hline Cochoro & $4.67 \mathrm{ab}$ & $33.0 \mathrm{c}$ & $1.0 \mathrm{bc}$ & $0.83 \mathrm{~cd}$ \\
Local round & $3.15 \mathrm{~b}$ & $14.87 \mathrm{~d}$ & 0.55 & $0.68 \mathrm{~d}$ \\
\hline MSE & 0.63 & 2.44 & 0.18 & 0.15 \\
\hline CV $(\%)$ & 12.95 & 6.10 & 16.24 & 14.30 \\
\hline
\end{tabular}

Note: Means with the same letter are not significantly different

\subsection{Number of Fruits}

The number of fruits per plant were significantly $(\mathrm{P}<0.001)$ different among the varieties (Table 1$)$. The maximum number of fruits per plant was obtained with 'Melka shola' (75.33) followed by 'Melka-selsa' (64.33) and the minimum number was in varieties, 'Fetan'(15.0) and'Mira-1'(15.67). On the other hand, 'Chali' and 'Cochoro' also showed the moderate fruit number per plant. The result agrees with Meseret et al. (2012) who reported that 'Fetan' variety showed the lowest fruit number when compared with other treatments in their experiment. The resultshowed an increasing tendency in the number of branches per plant with an increase in the fruit number. These results are also in close conformity with the findings of Sharma and Rastogi (1993) who reported significant variations among cultivars of tomato for number of branches and fruits per plant. In the glasshouse condition, the study showed that the number of fruits per plant was significantly $(\mathrm{P}<0.001)$ different among all the treatments. The maximum number of fruits per plant was recorded in 'Melka selsa'(35.33) followed by 'Melka shola'(20.33). The minimum number was observed in 'Fetan'(9.33), 'Kochoro' $(11.0)$ and 'Miya'(12.0). There was significantly $(\mathrm{P}<0.05)$ differences between open field and glass house experiments. These variable results may be due to biotic (temperature and relative humidity) factors. Some authors stated that the mean number of fruits per plant lay between 4.46 and 98.3 (Eshteshabul et al., 2010; Falak et al., 2011) and Agong et al., (2001) reported a value between 9.70 and 158.9, while in Ethiopia, Lemma, (2002) reported that the fruit number per plant between 26 and 62 .

\subsection{Insect Pests and Diseases}

Table2. Number of fruits infested by insects and disease per plant under open field condition.

\begin{tabular}{|c|c|c|c|}
\hline Treatments & $\begin{array}{c}\text { No. of fruit infested by } \\
\text { insect pests }\end{array}$ & $\begin{array}{c}\text { No. of fruit infested } \\
\text { by diseases }\end{array}$ & $\begin{array}{c}\text { General performance Visual } \\
\text { observation (0-5) rating }\end{array}$ \\
\hline Miya & $4.33 \mathrm{a}$ & $2 . .0 \mathrm{~d}$ & 2 \\
\hline Chali & $2.67 \mathrm{bc}$ & $3.0 \mathrm{~cd}$ & 4 \\
\hline Fetan & $2.33 \mathrm{bc}$ & $5.0 \mathrm{c}$ & 3 \\
\hline Melka alsha & $3.33 \mathrm{ab}$ & $26.67 \mathrm{a}$ & 3 \\
\hline Melka shola & $1.67 \mathrm{c}$ & $28.67 \mathrm{a}$ & 3 \\
\hline Cochoro & $2.67 \mathrm{bc}$ & $14.0 \mathrm{~b}$ & 3 \\
Local round & $1.57 \mathrm{c}$ & $4.83 \mathrm{c}$ & \\
\hline MSE & 0.62 & 1.47 & \\
\hline CV $(\%)$ & 22.32 & 11.19 & \\
\hline
\end{tabular}

The major insect pests, tomato fruit worm, Helicoverpa armigera, tomato leaf miner, Tuta absoluta, Red spider mite, Tetranychus evans and white fly, Bemasi tabaci were recorded severely damaging the tomato plants during all growth stages. Insect pest damages were found significantly $(\mathrm{P}<0.001)$ different among all treatments (Table 2). The number of fruits per plant damaged (bored) by insect pests were counted and the highest score was from 'Miya' (4.33/plant) and the lowest fruit damaged counted on 'Melka shola', (1.67/plant) while under glasshouse condition, the maximum fruit bored were observed in 'Melka selsa' (4.67) and the lowest was observed in 'Fetan' and 'Melka shola' one fruit each per plant. Dobson et al (2002) reported the African bollworm, also known as the tomato fruit worm, is one of the most destructive insect pests of tomato, causing yield losses as high as 70\% due to fruit boring. The tomato leafminer, Tuta absoluta (Meyrick), was recorded in Ambo University 
campus, Ethiopia for the first time in glasshouse and open field. Leaves and fruit infestation was recorded in tomato in glasshouse as well as in open field (Fig 4). The present study was indicated that the leaves damaged by this insect significantly $(\mathrm{P}<0.01)$ different among all treatments (Table 2$)$.

Rating scale 1 = Very poor $2=$ Poor $3=$ Good $\quad 4=$ Very good $5=$ Excellent

Early blight and blossom end rot diseases were observed during the study period. The data was significantly $(\mathrm{P}<0.001)$ different among all the treatments. Early blight primarily foliage and cause fruit to rot near the stem in late fall (Fig 1). There was considerably more blossom-end-rot affected fruit of 'Melka salsa' and 'Melka shola' varieties (Fig 2; Table 2).

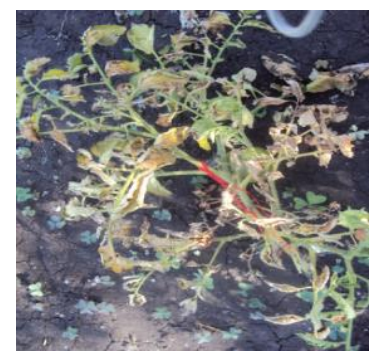

Figure1. Early blight

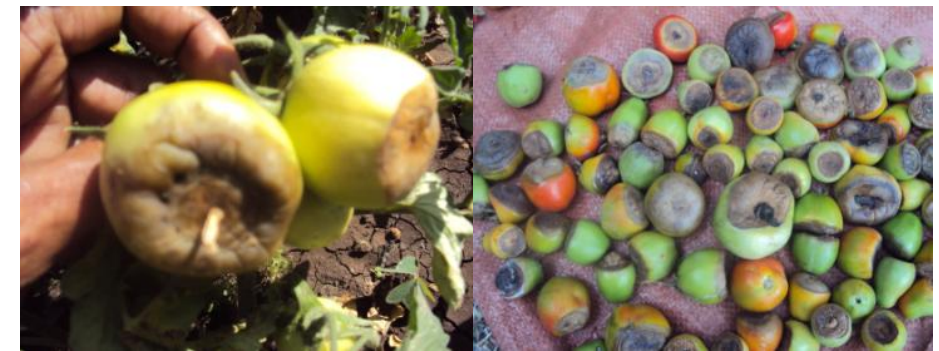

Figure2. Blossom end-rot ('Melka shola' and 'Melka salsa' varieties)
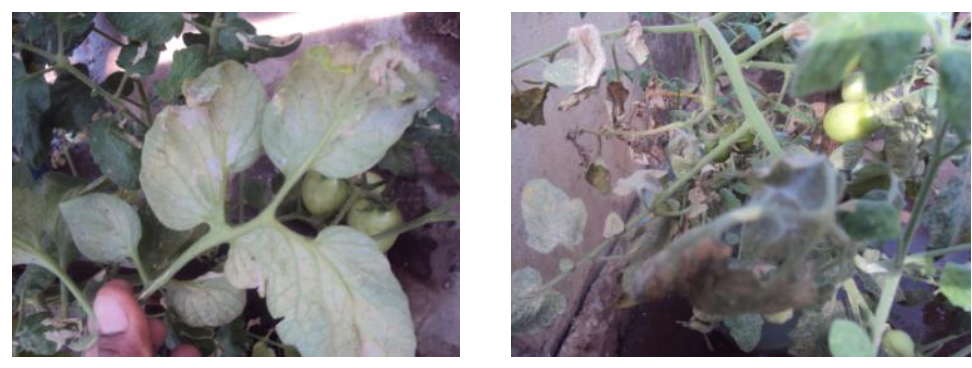

Figure3. Infestation of Red spider mite in glasshouse
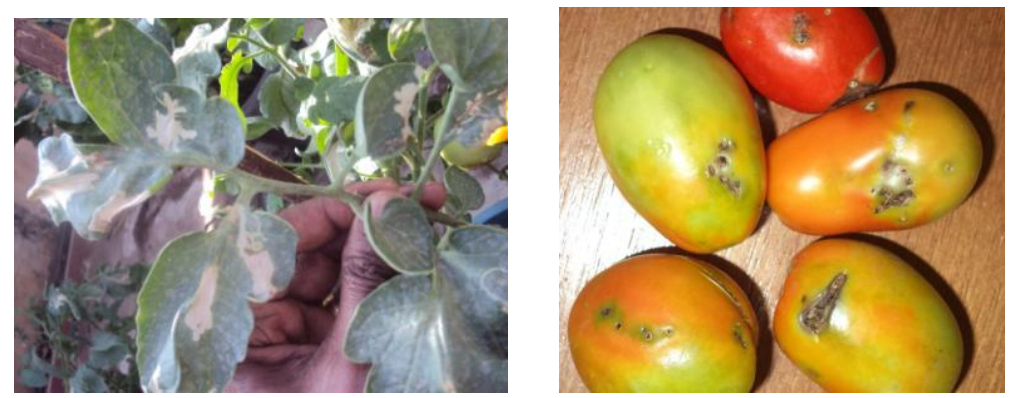

Figure4. Infestation of Tuta absoluta on tomato leaves and fruits

Table3. No. of fruits infested by insects and disease per plant under glasshouse.

\begin{tabular}{|c|c|c|c|}
\hline Treatments & $\begin{array}{c}\text { No. of fruit infested by } \\
\text { insect pests }\end{array}$ & $\begin{array}{c}\text { No. of fruit infested by } \\
\text { diseases }\end{array}$ & $\begin{array}{c}\text { No of leaf infested by Tuta } \\
\text { absolute per plant }\end{array}$ \\
\hline Miya & $1.67 \mathrm{~cd}$ & $2.33 \mathrm{c}$ & $14.03 \mathrm{~b}$ \\
\hline Chali & $2.67 \mathrm{~b}$ & $1.0 \mathrm{~d}$ & $17.13 \mathrm{ab}$ \\
\hline Fetan & $1.0 \mathrm{~d}$ & $1.67 \mathrm{~cd}$ & $17.07 \mathrm{ab}$ \\
\hline Melka salsa & $4.67 \mathrm{a}$ & $11.67 \mathrm{a}$ & $10.07 \mathrm{c}$ \\
\hline Melka shola & $1.0 \mathrm{~d}$ & $4.0 \mathrm{~b}$ & $14.67 \mathrm{~b}$ \\
\hline Cochoro & $2.0 \mathrm{~b}$ & $1.0 \mathrm{~d}$ & $18.6 \mathrm{a}$ \\
Local round & $0.8 \mathrm{~d}$ & $1.1 \mathrm{~d}$ & $16.43 \mathrm{~b}$ \\
\hline MSE & 0.4 & 0.47 & 1.61 \\
\hline CV $(\%)$ & 18.84 & 13.05 & 10.41 \\
\hline
\end{tabular}

In general, the visual observation of diseases showed that 'Melka shola' and 'Melks salsa' were highly affected by blossom-end-rot (28.67) and (26.67), respectively. The other treatments were not affected by blossom-end-rot but damaged by other diseases under open field condition (Table 3). Similarly under glass house condition 'Melka salsa' (11.67) and 'Melka shola' (4.06) were recorded (Table 2). The other treatments were highly affected by early blight. Tadesse et al. (2001) reported that, lower relative humidity promoted the uptake and accumulation of Calcium into the blossom-end- 
Evaluation of Improved Tomato Varieties (Lycopersicon esculentum Mill.) Performance against Major Insect Pests under Open Field and Glasshouse Conditions

rot portion of sweet pepper compared to those exposed to a higher relative humidity. The incidence of blossom-end rot effect was under question in both varieties. Some authors stated that, may be this lopped due to the limited capacity of the plant to regulate the internal distribution of calcium, in particular the continued flow towards organs with low evapotranspiration rapid growth such as fruit (Franco et al., 1994).

\section{MARKeTABLe Fresh Fruit Yield}

Under open field study, marketable fresh fruit yield result indicated significant variations among the varieties (Table 1). 'Chali' recorded maximum marketable fresh fruit yield per plant $(2.0 \mathrm{~kg})$ followed by 'Miya' $(1.3 \mathrm{~kg})$, 'Melka salsa $(1.05 \mathrm{~kg})$, and 'Cochoro' $(1.0 \mathrm{~kg})$. Minimum fresh fruit yield $(0.5 \mathrm{~kg})$ was recorded by 'Fetan'. The maximum fresh fruit yield of this variety may be attributed to the maximum fruit weight per plant (table 1). These results agree with Meseret et al. (2012) who reported minimum marketable fruit yield for the variety 'Fetan'.

Table4. No. of branch, number of fruit, marketable yield and non-marketable yield per plant under glasshouse.

\begin{tabular}{|c|c|c|c|c|}
\hline Treatments & $\begin{array}{c}\text { No. of branches per } \\
\text { plant }\end{array}$ & $\begin{array}{c}\text { Number of fruit per } \\
\text { plant }\end{array}$ & $\begin{array}{c}\text { Marketable yield per } \\
\text { plant }\end{array}$ & $\begin{array}{c}\text { Unmarketable } \\
\text { yield per plant }\end{array}$ \\
\hline Miya & $3.67 \mathrm{bc}$ & $12.0 \mathrm{~cd}$ & $1.2 \mathrm{~b}$ & $1.63 \mathrm{~d}$ \\
\hline Chali & $4.67 \mathrm{abc}$ & $13.33 \mathrm{c}$ & $0.31 \mathrm{~d}$ & $2.41 \mathrm{~b}$ \\
\hline Fetan & $3.33 \mathrm{c}$ & $9.33 \mathrm{~d}$ & $0.54 \mathrm{c}$ & $1.82 \mathrm{c}$ \\
\hline Melka salsa & $4.33 \mathrm{abc}$ & $35.33 \mathrm{a}$ & $0.62 \mathrm{c}$ & $3.42 \mathrm{a}$ \\
\hline Melka shola & $5.0 \mathrm{ab}$ & $20.33 \mathrm{~b}$ & $2.06 \mathrm{a}$ & $2.25 \mathrm{~b}$ \\
\hline Cochoro & $5.33 \mathrm{a}$ & $11.0 \mathrm{c}$ & $0.35 \mathrm{~d}$ & $1.25 \mathrm{e}$ \\
Local round & $3.0 \mathrm{c}$ & $9.12 \mathrm{~d}$ & $0.61 \mathrm{c}$ & $1.62 \mathrm{~d}$ \\
\hline MSE & 0.83 & 2.73 & 0.45 & 0.09 \\
\hline CV $(\%)$ & 18.91 & 16.17 & 5.37 & 4.36 \\
\hline
\end{tabular}

Note: Means with the same letter are not significantly different

\subsection{Fresh Fruit Weight Under Open Field}

Data in (Table 5) revealed that variety 'Chali' with $3.24 \mathrm{~kg}$ fresh fruit weight per plant was significantly yield higher when compared to 'Melka shola', and 'Miya' both of which gave a remarkably good fruit weight per plant of 2.69 and $2.46 \mathrm{~kg}$, respectively. 'Fetan' recorded the minimum fruit weight per plant $(1.13 \mathrm{~kg})$ followed by 'Cochoro' $(1.83 \mathrm{~kg})$ and Melka salsa $(1.99 \mathrm{~kg})$. Jiregna (2013) also reported differences in fruit weight among varieties of tomato put under evaluation of agronomic performance and lycopene variation in tomato at Mizan agro-ecology (South western Ethiopia).

Table5. Total fresh fruit yield weight in kilogram per plant under open field and glasshouse condition

\begin{tabular}{|c|c|c|}
\hline Treatments & $\begin{array}{c}\text { Total fresh yield wt per plant in kg } \\
\text { (Open field) }\end{array}$ & $\begin{array}{c}\text { Total yield per plant in kg } \\
\text { (Glass house) }\end{array}$ \\
\hline Miya & $2.46 \mathrm{bc}$ & $2.84 \mathrm{~b}$ \\
\hline Chali & $3.24 \mathrm{a}$ & $2.56 \mathrm{c}$ \\
\hline Fetan & $1.13 \mathrm{~d}$ & $2.37 \mathrm{c}$ \\
\hline Melka salsha & $1.99 \mathrm{c}$ & $4.04 \mathrm{a}$ \\
\hline Melka shola & $2.69 \mathrm{ab}$ & $4.28 \mathrm{a}$ \\
\hline Cochoro & $1.83 \mathrm{c}$ & $1.61 \mathrm{~d}$ \\
Local round & $1.15 \mathrm{~d}$ & $1.72 \mathrm{~d}$ \\
\hline MSE & 0.34 & 0.14 \\
\hline CV $(\%)$ & 15.16 & 4.61 \\
\hline
\end{tabular}

Note: Means with the same letter are not significantly different

\subsection{Fresh Fruit Weight Under Glasshouse}

Variety 'Melka selsa' and 'Melka shola' gave significantly higher total fresh fruit yield of (4.02) and (4.28) $\mathrm{kg}$ per plant, respectively than other varieties. The differences between 'Chali' and 'Fetan' were not significant. Lowest total fresh fruit yield of 1.72 and $1.61 \mathrm{~kg}$ per plant were recorded by 'Cochoro' and Local round, respectively. According to Fayaz et al. (2007) differences in total fruit yield might be due to differences in fresh fruit yield and nature of fruits in term of their succulence and dry matter content. 
'Melka shola' produced significantly maximum weight of marketable fresh fruit yield per plant 2.06 over other varieties. 'Melka selsa', 'Fetan' and 'Local round' with 0.62, 0.54 and 0.35 marketable fresh weight per plant, respectively. The intermediate marketable weight per plant was recorded by 'Miya' $1.2 \mathrm{~kg}$ per plant.

\section{CONCluSion}

On the basis of this finding tomato varieties 'Chali' and 'Melka shola' gave maximum fresh fruit yield under open field while varieties 'Melka shoal' and 'Melka salsa' were showed maximum fresh fruit yield per plant in glasshouse. Similarly, the general performance of 'Chali' and 'Cochoro' relatively had with better performance when compared with other treatments. Therefore, the above varieties were recommended as for open field cultivation and glasshouse conditions based on the performance they showed during the study periods.

On other hands, performance based on pest resistance of the varieties, specifically against Tuta absoluta, late and early blight diseases, and blossom-end-rot problems on the varieties (Melka shola and Melka salsa) needs further investigations.

\section{ACKNOWLEDGEMENT}

The author would likes to acknowledge Professor T. Salvaraj for editing the manuscript and Ambo University College of Agriculture and Veterinary Science for providing me the experimental fields and other inputs.

\section{REFERENCES}

[1] Agong SG, Schittnhelm S, Friedt and W (2001) Genotypic Variation of Kenyan tomato (Lycopersicon esculentum (Mill.) germplasm. Journal of food technology in Africa 6, 13-17.

[2] Ambecha O. Gemechis, Paul S, and Bezabih E (2012) Tomato Production in Ethiopia: Constraints and Opportunities.

[3] Baloch FA (1994) Vegetable crops. In: Horticulture National Book Foundation, Islamabad. 508p.

[4] Central Statistic Authority (2012) Report of Federal Democratic Republic of Ethiopia, Statistical Report on Socio-Economic Characteristics of the Population in Agricultural Households, Land Use, Area and Production of Crops. Addis Ababa, Ethiopia.

[5] Montgomery DC. (2005) Design and Analysis of Experimentals, 6 ed. John Wiley and Sons Inc.,USA., 97: 203

[6] SAS (2002) Statistical Analysis System Software. Ver. 9.0. SAS Institute InC., Carry. NC.

[7] Ethiopia Agricultural Research Organization (EARO). (2004) Directory of released crop varieties and their recommended cultural practices. Ethiopian Agricultural Research Organization, Addis Ababa, Ethiopia.

[8] Lemma D (2002) Tomatoes Research Experience and Production Prospects. Research Report No. 43. Ethiopian Agricultural Research Organization, Addis Ababa, 1(33): 46.

[9] Jiregna TD (2013) Evaluation of Agronomic Performance and Lycopene Variation in Tomato (Lycopersicon esculantum Mill.) Genotypes in Mizan, Southwestern Ethiopia. World Applied Sciences Journal 27 (11): 1450-1454

[10] Fayaz A, Obedullah K, Sair S, Akhtar and H, and Sher A (2007) Performance evaluation of tomato cultivars at high altitude. Sarhad J. Agric. Vol. 23, No. 3 Pp. 582-585.

[11] Falak N, Ihsan UI, Syed A, Abduls S, and Abdur R (2011) Studies on growth, yield and nutritional composition of different tomato cultivars Battal Vally of district Mansehra, Khyber Pakhtunkhwa, Pakistan. Sarhad Journal ofAgriculture 27 (4), 570-571.

[12] Eshteshabul M, Hakim MA, Amanullah ASM, and Ahsanullah ASM (2010) An Assessment of physiochemical properties of some tomato genotypes and varieties grown at Rangnur. Bangladish Research publication Journal 4 (3), 135-243.

[13] Sharma SK, and Rastogi KB (1993) Evaluation of some tomato cultivars for seed production Under mid hill conditions of Himachal Pardesh. Annals of Agric. Res. India. 14(4): 494-496.

[14] Birhanu K and and K Tilahun (2010) Fruit yield and quality of drip-irrigated tomato under deficit irrigation AJFAND Volume 10 No. 2 
Evaluation of Improved Tomato Varieties (Lycopersicon esculentum Mill.) Performance against Major Insect Pests under Open Field and Glasshouse Conditions

[15] Dobson H, Cooper J, Manyangarirwa W, Karuma J, and Chiimba W (2002) Integrated Vegetable Pest Management - Safe and sustainable protection of small-scale brassicas and tomatoes. Natural Resources Institute, University of Greenwich, UK.

[16] Meseret D, Ali M, and Kassahun B (2012) Evaluation of tomato (Lycopersicon esculentum Mill.) Genotypes for yield and yield components. The Africa Journal of plant science and Bioltechnology 6 (special issue 1), 45-49.

[17] Franco JA, Banon S, and Madrid R (1994) Effect of a protein hydrolysate applied by fertigation on the effectiveness of calcium as a corrector of blossom-end rot in tomato cultivated saline conditions. Sci. Hort. 57: 283-292.

[18] Tadesse T, Nichols MA, Hewett EW, and Fisher KJ (2001) Relative humidity around the fruit influence the mineral composition and incidence of blossom-end-rot in sweet pepper. J. Hort. Biotechnol. 76: 9-16. 